\title{
Pengaruh Komunikasi Yang Efektif Dan Motivasi Terhadap Kinerja Pegawai Pada Dinas Perhubungan Kabupaten Karo
}

\author{
Menanti Sembiring \\ Staf Pengajar Fakultas Ekonomi Universitas Quality \\ Email: menantisembiring@gmail.com
}

\begin{abstract}
Abstrak
Penelitian ini bertujuan untuk mengkaji pengaruh komunikasi dan motivasi kerja yang efektif terhadap kinerja karyawan di Dinas Perhubungan Kabupaten Karo. Jumlah populasi penelitian ini adalah sekitar 46 orang dan semuanya diciptakan sebagai sampel atau sampel total. Untuk menguji hipotesis yang diajukan dapat dilakukan pengujian parsial, pengujian simultan dan koefisien determinasi. Hasil penelitian menunjukkan bahwa secara parsial, variabel komunikasi dan motivasi efektif berpengaruh signifikan terhadap kinerja karyawan di Dinas Perhubungan Kabupaten Karo, dimana nilai t hitung dalam variabel komunikasi adalah 2.253 dan nilai yang dihitung berdasarkan variabel movasi adalah 4.359, dimanapun nilai t tabel adalah 1.679. Dengan cara uji simulataneous, Fhitung dihitung dengan 19.582 dan nilai Ftabel adalah 3.204. Dapat disimpulkan bahwa dengan cara uji simultan, variabel komunikasi dan motivasi efektif berpengaruh signifikan terhadap kinerja karyawan juga di Dinas Perhubungan Kabupaten Karo. Hasil regresi linier berganda diperoleh dengan persamaan y $=8,638+0,246 \times 1+0,521 \times 2+e$. Nilai koefisien determinasi menyatakan bahwa 0,477 atau 47,70\% kinerja karyawan di Dinas Perhubungan Kabupaten Karo dipengaruhi oleh komunikasi dan motivasi yang efektif dan sisanya $52,30 \%$ dipengaruhi oleh faktor lain yang tidak dilakukan pada penelitian ini.
\end{abstract}

\section{Kata kunci: Komunikasi, Motivasi, Kinerja, Efektif}

\begin{abstract}
This research is aim to review the influence of effective communication and motivation towards employee performance at Transportation Department Karo District. The sum of population of this research is about 46 people and all of them is created as sample or total sample. To test the hypothesis which is submitted can be done by partial testing, simultaneous testing and coefficient of determination. The result of this research shows that in partial way, the variable of effective communication and motivation is significantly influence the perfomance employee at Transportation Department Karo district, where $t_{\text {calculated }}$ value in variable of communication is 2,253 and $t_{\text {calculated }}$ value in variable of movation is 4,359 , wherever the value of $t$ table is 1,679. By simulataneous testing way, $F_{\text {calculated }}$ is obtained with 19,582 and the value of $F_{\text {table }}$ is 3,204. It can be concluded that by simultaneous testing way, variable of effective communication and motivation is significantly influence the employee performance too at Transportation Department Karo district. The result of multiple linier regression is obtained by the equation $y=8,638+0,246 x_{1}+0,521 x_{2}+e$. The value of coefficient of determination stated that 0,477 or 47,70\% of employee performance in Transportation Department Karo district is influenced by effective communication and motivation and the rest $52,30 \%$ is influenced by another factor which is not conducted on this research.
\end{abstract}

Keywords : Communication, Motivation, Performance, Effective 


\section{PENDAHULUAN}

Keberhasilan sebuah organisasi dalam mencapai tujuannya tidak terlepas dari terjalinnya komunikasi yang baik. Komunikasi yang berjalan secara efektif dalam organisasi akan memudahkan setiap orang melaksanakan tugas yang menjadi tanggung jawabnya . Untuk itu seorang pimpinan dituntut agar mampu melakukan komunikasi secara efektif, karena mereka akan memberi instruksi, pengarahan, memotivasi bawahan, melakukan pengawasan dan lain-lain. Komunikasi ini tidak hanya terjadi antara atasan dengan bawahan tetapi juga antara sesama rekan kerja, agar setiap pegawai dapat bekerja dengan baik. Jika komunikasi ini tidak berjalan dengan baik akan menyebabkan terjadinya miss communication yang akan bisa berpengaruh terhadap motivasi kerja dari pegawai. Hal ini tentu sangat tidak diharapkan karena dapat berpengaruh terhadap kinerja mereka. Banyaknya pekerjaan yang seharusnya dapat diselesaikan sesuai target waktu tapi karena kurangnya komunikasi ini dapat membuat pekerjaan tidak terselesaikan sesuai target waktu yang telah ditetapkan.

Organisasi merupakan suatu kesatuan sosial yang terdiri dari sekelompok manusia yang saling berinteraksi, karena itu di dalam sebuah organisasi sangat diperlukan komunikasi yang berjalan dengan baik sehingga aktivitas kerja dapat dioptimallkan. Semakin efektif komunikasi yang dibina dalam setiap bagian organisasi maka semakin produktiflah setiap pegawai dalam melaksanakan tugasnya. Suatu komunikasi dikatakan efektif apabila penerima pesan dapat menginterprestasikan pesan yang dia terima sebagaimana yang dimaksudkan oleh pengirim pesan.

Menurut Harapan dan Ahmad (2014:2): Komunikasi adalah suatu proses penyampaian pesan dari seseoarng kepada orang lain melalui proses tertentu sehingga tercapai apa yang dimaksudkan atau diinginkan oleh kedua belah. Menurut Sutrisno (2011:49): Komunikasi merupakan suatu proses dua arah yang menghasilkan transmisi dan pengertian antar individu (baik secara verbal maupun non pihakverbal). Agar setiap orang yang ada dalam organisasi dapat melaksanakan tugasnya dengan baik maka haruslah terbina suatu sistem komunikasi yang baik pula. Seorang pimpinan akan dapat menjalankan fungsi manajemen seperti fungsi planning, organizing, actuating dan controlling jika didapat berkomunikasi secara baik dengan bawahannya.

Untuk mengetahui apakah komunikasi pada Dinas Perhubungan Kabupaten Karo telah berjalan secara efektif dibuat indikator sesuai dengan pendapat Siagian ( $2010: 57)$, yakni

1. Ketrampilan dalam menyusun pesan

2. Sikap yang tepat dalam penyampaian pesann 
3. Pengetahuan tentang latar belakang, tingkat pendidikan penerima pesan

4. Respon yang diharapkan dari penerima pesan

Kemampuan sebuah organisasi dalam mencapai tujuannya sangat ditentukan oleh tinggi rendahnya motivasi kerja pegawainya. Tugas dari pimpinan untuk dapat mendorong motivasi kerja dari setiap bawahannya. Motivasi merupakan perilaku manusia yang mendorong mereka untuk mau dan rela menyelesaikan tugasnya dengan semangat dan penuh rasa tanggung jawab.

Menurut Fahmi (2014 : 107) motivasi adalah aktivitas perilaku yang memenuhi kebutuhan-kebutuhan yang dinginkan. Sutrisno (2011 : 109) mengartikan motivasi adalah suatu faktor yang mendorong seseorang untuk melakukan suatu aktivitas tertentu, oleh karena itu motivasi sering kali diartikan pula sebagai faktor pendorong perilaku seseorang. Karena itu penting kiranya pimpinan memberikan motivasi yang tepat kepada setiap bawahannya karena akan dapat mendorong prestasi kerja sehingga akan menguntungkan bagi organisasi. Menurut Agustini (2011: 32) terdapat berbagai tujuan dari pemberian motivasi pada pegawai, yakni :

1. Meningkatkan semangat kerja karyawan

2. Meningkatkan moral dan kepuasan kerja karyawan

3. Meningkatkan produktivitas kerja karyawan

4. Mempertahankan kestabilan karyawan
5. Meningkatkan

kedisiplinan karyawan

6. Meningkatkan prestasi kerja karyawan

7. Mengefektifkan pengadaan karyawan

8. Menciptakan suasana dan hubungan kerja yang baik

9. Meningkatkan loyalitas, kreativitas, dan partisipasi karyawan

10. Meningkatkan tingkat kesejahteraan karyawan

11. Mempertinggi rasa tanggung jawab karyawan terhadap tugasnya

12. Meningkatkan efisiensi penggunaan alat-alat dan bahan baku

Lebih lanjut menurut Agustini (2011 : 46) terdapat beberapa ciri-ciri pegawai yang memiliki motivasi kerja yang baik, dan ciri ini dapat dijadikan indikator untuk mengukur apakah program motivasi sudah berjalan dengan baik atau tidak, yakni :

1. Bekerja sesuai standard

2. Senang bekerja

3. Merasa berharga

4. Bekerja keras

5. Sedikit pengawasan

6. Semangat juang tinggi

7. Disiplin

Tidak ada satu organisasi manapun yang berkeinginan kinerjanya tidak baik. Kinerja organisasi sangat ditentukan oleh kinerja para pegawainya, jika para pegawai memiliki kinerja yang baik maka kinerja organisasi akan baik. Menurut Mangkunegara (2013 : 67) kinerja 
adalah hasil kerja secara kualitas dan kuantitas yang dicapai oleh seorang karyawan dalam melaksanakan tugasnya sesuai dengan tanggung jawab yang diberikan kepadanya. Menurut Wilson $(2012$ : 231) Kinerja adalah hasil pekerjaan yang dicapai seseorang berdasarkan persyaratan-persyaratan pekerjaan (Job requirement)

Kinerja seorang pegawai merupakan kesuksesan yang ditunjukkan oleh seorang pegawai didalam dia melaksanakan tugas yang menjadi tanggung jawabnya. Kemampuan pegawai dalam melaksankan pekarjaanya sangat ditunjang oleh berbagai faktor yang harus diperhatikan oleh setiap organisasi. Untuk mengetahui apakah seorang pegawai memiliki kinerja yang baik atau tidak maka setiap organisasi harus melakukan penilian terhadap kinerja para pegawainya. Untuk mengukur kinerja pegawai tersebut diperlukan indikator'

Didalam penelitian ini indikator yang digunakan untuk mengukur kinerja pegawai pada Dinas Perhubungan Kabupaten Karo adalah sebagai berikut :

1. Kuantitas Kerja

2. Kualitas Kerja

3. Inisiatif

4. Keandalan

5. Kerajinan

6. Sikap

7. Kehadiran

Berdasarkan latar belakang masalah, maka permasalahan dalam penelitian ini dapat dirumuskan sebagai berikut apakah Komunikasi dan motivasi kerja berpengaruh signifikan terhadap kinerja pegawai DinasnPerhubungan Kabupaten Karo?

\section{METODE PENELITIAN}

Populasi pada penelitian ini adalah seluruh pegawai negeri sipil yang ada pada Dinas Perhubungan Kabupaten Karo yang berjumlah 46 orang. Mengingat populasi jumlahnya relatif kecil maka seluruh pepolasi akan dijadikan sampel penelitian atau sampel total. Variabel Independen $(\mathrm{X})$ terdiri dari Komunikasi Yang Efektif $\left(\mathrm{X}_{1}\right)$ dan Motivasi $\left(\mathrm{X}_{2}\right)$ Variabel Dependen $(\mathrm{Y})$ adalah Kinerja Pegawai Dinas Perhubungan Kabupaten Karo (Y)

Metode analisis data yang digunakan dalam penelitian ini adalah metode analisis deskriptif merupakan metode dengan mengumpulkan dan menafsirkan data yang ada sehingga memberikan gambaran yang jelas mengenai permasalahan yang sedang diteliti dan metode Analisis Kuantitatif. Dengan metode analisis kuantitatif digunakan beberapa metode analisis regresi linier berganda.

Model persamaan regresinya adalah : $Y$ $=\mathrm{a}+\mathrm{b}_{1} \mathrm{X}_{1}+\mathrm{b}_{2} \mathrm{X}_{2}+\mathrm{e}$

Keterangan :

$\mathrm{Y} \quad=$ Kinerja Pegawai

$\mathrm{a} \quad=$ Konstanta

$\mathrm{b}_{1} \mathrm{~b}_{2}=$ Koefisien regresi

$\mathrm{X}_{1}=$ Komunikasi Yang Efektif

$\mathrm{X}_{2} \quad=$ Motivasi

$\mathrm{e} \quad=$ Error of term 
Pengujian hipotesis dilakukan dengan cara sebagai berikut :

a. Uji Simultan (Uji F)

Dilakukan untuk mengetahui bagaimana pengaruh variabel bebas (X) secara serempak terhadap variabel terikat (Y). Dengan kriteria pengujian sebagai berikut :

Ho : bi $=0$, artinya variabel bebas

(X) secara serempak tidak berpengaruh terhadap variabel terikat (Y)

Ho : bi $\neq 0$, artinya variabel bebas

(X) secara simultan berpengaruh terhadap variabel terikat $(\mathrm{Y})$

Kriteria pengambilan keputusannya adalah sebagai berikut :

Ho diterima jika $\mathrm{F}$ hitung $<\mathrm{F}$ tabel pada $\alpha 5 \%$

Ho ditolak jika $\mathrm{F}$ hitung $>\mathrm{F}$ tabel pada $\mu$ $5 \%$

b. Uji Parsial (Uji t)

Pengujian ini dilakukan untuk mengetahui apakah secara parsial variabel bebas ( $\mathrm{X}_{1}$ dan $\left.\mathrm{X}_{2}\right)$ berpengaruh signifikan terhadap variabel terikat $(\mathrm{Y})$

Dengan kriteria pengujian sebagai berikut :

Ho : bi $=0$, artinya variabel bebas $\left(X_{1}\right.$ dan $X_{2}$ ) secara parsial tidak berpengaruh terhadap variabel terikat (Y)
Ho : bi $\neq 0$, artinya variabel bebas

$\left(\mathrm{X}_{1}\right.$ dan $\left.\mathrm{X}_{2}\right)$ secara parsial berpengaruh terhadap variabel terikat (Y)

Kriteria pengambilan keputusannya adalah sebagai berikut

Kriteria pengambilan keputusannya adalah sebagai berikut:

Ho diterima jika $\mathrm{t}$ hitung $<\mathrm{t}$ tabel pada $\alpha 5$ $\%$

Ho ditolak jika hitung $>t$ tabel pada $\mu 5 \%$

c. Koefisien Determinasi $\left(\mathrm{R}^{2}\right)$

Digunakan untuk mengukur seberapa besar kemampuan variabel bebas yang dimasukkan dalam model untuk menjelaskan variabel terikat. Nilai koefisien determinasi berada antara 0 (nol) dan 1 (satu), artinya jika nilai $\mathrm{R}^{2}$ semakin mendakati nol maka kemampuan variabel bebas dalam menjelaskan variabel terikat sangat terbatas sebaliknya jika mendekati angka satu berarti kemampuan model menjelaskan variabel terikat semakin besar.

\section{HASIL DAN PEMBAHASAN}

Berdasarkan hasil regresi data yang telah diolah dengan menggunakan program SPSS versi 21 diperoleh hasil regresi linear berganda pada tabel di bawah ini : 
Tabel 1 Hasil Regresi Linear Berganda

\begin{tabular}{|c|c|c|c|c|c|c|}
\hline \multirow{2}{*}{\multicolumn{2}{|c|}{ Model }} & \multicolumn{2}{|c|}{$\begin{array}{c}\text { Unstandardized } \\
\text { Coefficients }\end{array}$} & $\begin{array}{l}\text { Standardized } \\
\text { Coefficients }\end{array}$ & \multirow[t]{2}{*}{$t$} & \multirow[t]{2}{*}{ Sig. } \\
\hline & & $B$ & $\begin{array}{l}\text { Std. } \\
\text { Error }\end{array}$ & Beta & & \\
\hline \multirow{3}{*}{1} & (Constant) & 8.638 & 5.322 & & 1.623 & .012 \\
\hline & Komunikasi & .246 & .109 & .274 & 2.253 & 029 \\
\hline & Motivasi & .521 & .119 & .530 & 4.359 &, 000 \\
\hline
\end{tabular}

Dari hasil pengolahan data seperti tertera pada tabel di atas maka dapat dibentuk persamaan regresi linear berganda sebagai berikut:

$Y=8,638+0,246 X_{1}+0,521 X_{2}+e$

Keterangan :

1. Nilai konstanta sebesar 8,638 dapat diartikan bahwa kinerja pegawai Dinas Perhubungan Kabupaten Karo akan tetap bernilai 8,638 pada saat komunikasi dan motivasi bernilai nol (tidak ada)

2. Koefisien regresi X1 sebesar 0,246 dapat diartikan bahwa kenaikan satu satuan komunikasi akan meningkatkan kinerja pegawai Dinas Perhubungan Kabupaten Karo sebesar 0,246 satuan.

3. Nilai $X 2=0,521$ dapat diartikan bahwa kenaikan satu satuan motivasi akan meningkatkan kinerja pegawai Dinas Perhubungan Kabupaten Karo sebesar 0,521 satuan.

Pada Tabel 4.11 menunjukkan hasil dari nilai thitung dari variabel komunikasi yang efektif diperoleh sebesar 2,253 sedangkan ttabel sebesar 1,679 pada tingkat kepercayaan $\alpha 5 \%(0,05)$ atau thitung $>$ tabel $(2,253>1,679)$. Maka keputusannya adalah Ho di tolak dan Ha diterima , ini berarti bahwa komunikasi yang efektif berpengaruh signifikan terhadap kinerja pegawai pada Dinas Perhubungan Kabupaten Karo

Untuk variabel motivasi diperoleh nilai thitung sebesar 4,359 dan dari tabel distribusi t diperoleh nilai tabel sebesar 1,679 , maka $t$ hitung $>t$ tabel $(4,359$ $>1,679$ ). Keputusannya adalah Ho di tolak dan Ha diterima , ini berarti motivasi berpengaruh signifikan terhadap kinerja pegawai pada Dinas Perhubungan Kabupaten Karo. Dari perhitungan di atas maka diketahui bahwa variabel yang mempunyai pengaruh paling dominan terhadap kinerja pegawai Dinas Perhubungan Kabupaten Karo adalah variabel motivasi kerja.

Untuk menguji apakah variabel komunikasi yang efektif dan motivasi secara simultan berpengaruh signifikan terhadap kinerja pegawai pada Dinas Perhubungan Kabupaten Karo digunakan uji statistic F (uji F) 
Tabel 2 Hasil Uji Simultan

\begin{tabular}{|c|c|c|c|c|c|c|}
\hline \multicolumn{7}{|c|}{ ANOVAa $^{a}$} \\
\hline & & $\begin{array}{l}\text { Sum of } \\
\text { Squares }\end{array}$ & Df & Mean Square & $\mathrm{F}$ & Sig. \\
\hline \multirow{3}{*}{1} & Regression & 132.686 & 2 & \multirow{3}{*}{$\begin{array}{r}66.343 \\
3.388\end{array}$} & \multirow[t]{3}{*}{19.582} & \multirow[t]{3}{*}{$.000^{\mathrm{b}}$} \\
\hline & Residual & 145.684 & 43 & & & \\
\hline & Total & 278.370 & 45 & & & \\
\hline
\end{tabular}

a. Dependent Variable: Kinerja Pegawai

b. Predictors : (Constant), Komunikasi, Motivasi

Pada Tabel 2 diperoleh hasil Fhitung sebesar 19.582 dan dari tabel distribusi F diperoleh nilai Ftabel sebesar maka Fhitung $>F_{\text {tabel }}(19,582>3,204)$ dan sig. $000<0$,. Maka keputusannya adalah Ho ditolak dan Ha diterima, artinya secara simultan variabel komunikasi yang efektif dan motivasi kerja berpengaruh

Tabel 3. Hasil Koefisien Determinasi R2 Model Summary

\begin{tabular}{|l|r|r|r|r|}
\hline Model & R & R Square & Adjusted R Square & $\begin{array}{c}\text { Std. Error of the Es- } \\
\text { timate }\end{array}$ \\
\hline 1 &, $690^{\mathrm{a}}$ &, 477 &, 452 & 1.84065 \\
\hline
\end{tabular}

a. Predictors: (Constant), Komunikasi, Motivasi.

Dari Tabel 4.3 dapat dilihat bahwa nilai koefisen $\mathrm{R}$ square sebesar 0,477 atau $47,70 \%$ ini memberi arti bahwa $47,70 \%$ variabel terikat yaitu Kinerja pegawai (Y) dapat dijelaskan oleh komunikasi yang efektif (X1) dan motivasi kerja (X2). Sedangkan sisanya sebesar 52,30 \% oleh variabel independen lainnya yang tidak dimasukkan dalam model penelitian ini seperti pelatihan, gaya kepemimpinan, kepuasan kerja, kesempatan pengembangan karier, disiplin kerja dan lain-lain signifikan terhadap kinerja pegawai Dinas Perhubungan Kabupaten Karo..

Untuk mengetahui seberapa besar kemampuan variabel komunikasi yang efektif dan motivasi terhadap variabel kinerja pegawai pada Dinas Perhunbungan Kabupaten Karo maka perlu diketahui besarnya nilai koefisien determinasi $\left(\mathrm{R}^{2}\right)$

\section{SIMPULAN}

Berdasarkan hasil analisis dan evaluasi, maka dapat disimpulkan Secara simultan menunjukkan bahwa variabel Komunikasi (X1) dan variabel Motivasi (X2) secara bersama-sama berpengaruh signifikan terhadap Kinerja Pegawai (Y) Dinas Perhubungan Kabupaten Karo. Secara parsial menunjukkan bahwa variabel Komunikasi yang Efektif (X1) dan Motivasi (X2) berpengaruh signifikan terhadap Kinerja Pegawai (Y) Dinas Perhubungan Kabupaten Karo. Dan variabel yang paling dominan 
mempengaruhi kinerja pegawai adalah variabel motivasI. Berdasarkan pengujan koefisien determinasi diperoleh nilai $\mathrm{R}$ square sebesar 0,477 atau 47,70 \% ini memberi arti bahwa bahwa $47,70 \%$ kinerja pegawai dipengaruhi oleh komunikasi yang efektif dan motivasi kerja Sedangkan sisanya sebesar 52,30 \% dipengaruhi oleh variabel lain yang tidak diteliti dalam penelitian ini seperti pelatihan, disiplin kerja, gaya kepemimpinan, kompensasi dan lain sebagainya. saran yang dapat diberikan antara lain mngingat variabel motivasi merupakan variabel yang lebih dominan maka perlu kiranya faktorfaktor yang dapat mendorong motivasi ini menjadi perhatian bagi pimpinan misalnya pimpinan dapat memberikan reward kepada pegawai yang mampu melaksanakan tugas dengan baik seperti kemudahan dalam promosi jabatan, memberi kesempatan untuk melanjutkan pendidikan dan dalam bentuk lainnya. Selain pemberian reward pimpinan juga bisa memberikan teguran baik secara lisan maupun secara tertulis bagi pegawai yang tidak melaksanakan pekerjaannya sesuai dengan peraturan yang telah ditetapkan. Komunikasi yang baik antar antara pimpinan dengan bawahan dan sesama pegawai yang selama ini telah berjalan dengan baik agar dapat dipertahankan dan ditingkatkan sehingga dapat meningkatkan motivasi kerja pegawai yang pada gilirannya akan berpengaruh bagi kinerja pegawai.

\section{DAFTAR PUSTAKA}

Agustini, Fauzia. 2010. Manajemen Sumber Daya Manusia Lanjutan. Medan. Madenatera.

Arikunto, Suharsimi 2009 . Manajemen Penelitian. Jakarta.PT.Rineka Cipta.

Bangun, Wilson, 2012, Manajemen Sumber Daya Manusia, Erlangga. Bandung

Cangara, Hafied. 2011, Pengantar Ilmu Komunikasi, Jakarta, PT.RajaGrafindo Persada

Dharma, Surya, 2010. Manajemen Kinerja. Edisi Ketiga. Yogjakarta. Pustaka Pelajar.

Harapan, Edi dan Ahmad Syarwani. 2014, Komunikasi Antar Pribadi Perilaku Insani Pendidikan. Jakarta. PT.RajaGrafindo Persada.

Hasibuan, Malayu SP 2010. Manajemen Sumber Daya Manusia. EdisiRevisi.Jakarta.Bumi Aksara.

Irham, Fahmi. 2014, Perilaku Organisasi Teori, Aplikasi dan Kasus. Bandung Alfabeta.

Mangkunegara, A.A. Anwar Prabu. 2014. Evaluasi Kinerja SDM. Bandung. Penerbit Refika Aditama.

Manajemen Sumber Daya Manusia Perusahaan. Bandung, PT. Remaja Rosdakarya

Peraturan Pemerintah Nomor 46 Tahun 2011 Tentang Penilaian Prestasi Kerja Pegawai Negeri Sipil.

Priansa,2014, Perencanaan dan Pengembangan SDM. Bandung. Alfabeta.

Sastrohadiwiryo, B.Siswanto. (2005). Manajemen Tenaga Kerja Indonesia: Pendekatan Administrasi dan Operasional.Jakarta.PT.Bumi Aksara.

Sedarmayanti. 2015,. Manajemen Sumber Daya Manusia. Bandung Refika Aditama 
(2009). Manajemen Sum-

ber Daya Manusia, Reformasi

Birokrasi dan Manajemen Pegawai Negeri Sipil. Bandung. PT. Refika Aditama.

Sangaji, Mamang Etta dan Sopiah, 2010. Metodologi Penelitian : Pendekatan Praktis Dalam Penelitian Yogjakarta. Andi Offset.

Siagian, Sondang. P. 2013. Manajemen Sumber Daya Мапиsia.Jakarta.PT.Bumi Aksara

Sugiyono. (2006). Metode Penelitian Bisnis. Cetakan Kesembilan. Penerbit Alfabeta.Bandung.

Sutrisno, Edy. 2009. Manajemen Sumber Daya Manusia.Edisi Pertama,Cetakan ke - 3, Jakarta.Kencana

-----------. Budaya Organisasi, 2011. Jakarta. Kencana Prenada.

Tika, Moh.Pabundo. 2010. Budaya Organisasi dan Peningkatan Kinerja Perusahaan.Jakarta.Bumi Aksara.

Trihendradi, C. 2013.Step By Step IBM SPSS 21. Yogyakarta. Andi Offset 